\title{
Research on Owner's Claims Based on Construction Project Delay Compensation
}

\author{
Yifan Han ${ }^{\mathrm{a}}$, Ling Yan \\ School of Management, Tianjin University of Technology, Tianjin 300384, China \\ a995531483@qq.com
}

\begin{abstract}
Research on owner's claims is insufficient in constructive engineering field, the composition and calculation way of the delay compensation is still not clear. Firstly, make definition of the delay compensation and its character. Secondly, analyze the reasons of delay, make specific division on the composition of the delay compensations on the basis of predecessors' research results and put forward a kind of calculation way. Finally, study on the limitation of the delay compensations based on the calculation of delay compensations. According to the analysis of these three aspects, put forward rational methods for confirming the delay compensations.
\end{abstract}

Keywords: construction project, delay compensation, owner's claims, limitation.

\section{Introduction}

Large projects in the engineering practice are often faced with many problems, such as large construction scale, long construction period, complicated construction conditions and the coordination among construction participants is obstructed [1]. Delayed completion is inevitable in the perform process of construction contract. But research on the claim for the owner is defective. Specific cost composition and calculation method of overdue compensation is still not clear. Therefore the paper research on the claims of the owners for compensation based on the engineering overdue.

In this paper, the overdue compensation research mainly divided into the following three aspects: Firstly, to define the concept of the overdue compensation, and its properties; Secondly, to analyses the reasons of overdue, and divide the overdue compensation costs specifically and put forward calculation method on the basis of predecessors' research. Finally, research on the overdue compensation limit based on delay compensations calculated. Through the above three stages of the research, provide reasonable basis for overdue compensation. The study can help reduce the chance of contract dispute during contract performance, guarantee the realization of project objectives.

\section{Theory Analysis of Delay Compensation}

\subsection{Definition of Delay Compensation}

The essence of overdue compensation is the owner's claims for compensation [2]. It is the owner's compensation demand from the contractor due to the delay of the actual losses. Therefore the paper will inductive similar concept combining the relevant specification and contract documents, as shown in table 1.

Table 1 shows that the term of similar concept in specification and contract is different, but the essence is the same. In addition, Construction project quantities list valuation specification (GB 50500-2013) defined the completion of overdue penalty due to breach of contract: If the delay is caused by the contractor, calculation method and the upper limit of completion overdue penalty due to breach of contract can be promised in the special terms of the contract. After paying the completion of overdue penalty due to breach of contract, the contractors are not released from continuing to complete the work and the obligation to repair the defect. The nature of the overdue compensation and completion overdue penalty due to breach of contract is the same, it is the compensation contractors pay to the owners. 
Table 1. Relevant concepts about delay compensation

\begin{tabular}{|c|c|c|}
\hline Name of the specification & $\begin{array}{l}\text { Regulation } \\
\text { number }\end{array}$ & Related notion \\
\hline $\begin{array}{l}\text { Construction project quantities list valuation specification } \\
\text { (GB 50500-2013) }\end{array}$ & 9.12 & overdue compensation \\
\hline $\begin{array}{l}\text { The } 99 \text { edition of FIDIC contract conditions for } \\
\text { construction (new red book) }\end{array}$ & 8.7 & overdue for damages \\
\hline $\begin{array}{l}\text { The } 2007 \text { edition of the standard construction tender } \\
\text { documents }\end{array}$ & 6.5 & $\begin{array}{l}\text { completion of overdue penalty } \\
\text { due to breach of contract }\end{array}$ \\
\hline $\begin{array}{l}\text { The project construction contract (demonstrative text)(GF } \\
\qquad-2013-0201)\end{array}$ & 7.5 & $\begin{array}{l}\text { completion of overdue penalty } \\
\text { due to breach of contract }\end{array}$ \\
\hline
\end{tabular}

\subsection{The nature of the delay compensation}

In practice, the overdue compensation the owner and the contractor appointed in special terms in the contract is often considered as fine or penalty. But the overdue compensation is completely different from these two concepts. Overdue compensation amount is the loss amount that the party compensated lead to the other party defaults. While the latter with a nature of punishment, which the amount is usually greater than the actual loss. The nature of the overdue compensation and the fine is different, overdue compensation is compensatory but not disciplinal.

\section{The Cause of the Delay Compensation and Expenditure Pattern}

\subsection{Analysis of delay reason}

In practice, there are many reasons that lead to project delay, such as complicated construction conditions and numerous construction participants. To determine the cause of delay caused by contractor's own reasons, we should analyze the reasons of the project delay, then analyze the reasons of the contractors. The reasons of project delay caused by contractors are as follows: undeserved construction organization, idling of the labor force and shutdown, rework on account of the quality regulation in the contract, the insufficient allocation of resources, work delay, inefficient labor productivity, the suppliers delays and so on.

\subsection{Delay compensation fee structure analysis}

(1)Direct damages

Direct loss refers to the damaged parts caused by contractor's default behavior, including the subsequent influence of the project itself and deferred effect. When the overdue event occurs, in combination with the specific situation of each construction project, interest groups indicators involved can be decomposed. Then make classified summary calculation. The exact makeup of direct damage in the delay compensations is researched to some extent. Experts and scholars in this field have obtained a series of research achievement. Scholars generally believe that the increased interest on loans should be incorporated in the direct loss. Most scholars believe that additional supervision fee should also be incorporated in the direct loss. But whether the rent, maintenance costs and other expenses should be incorporated in the direct loss, there is no consistent view.

(2)Indirect loss

Indirect loss refers to the loss besides the direct loss that engineering overdue impact to construction project $^{[3]}$. In the view of civil law, indirect loss can also be understood as the benefit should be obtained but actually not be obtained because of the default. From this perspective, indirect loss in overdue compensation fee structure refers to the interest that the owner expected (including expected profit, reducing production efficiency, business surplus) in the construction contract.

\section{Calculation of Delay Compensation}

\subsection{Key factors confirmation of the calculation of delay compensation}

Delay compensation fees $=$ compensated amount of each calendar day $\times$ delay days. Therefore, the compensated amount of each calendar day and the days for delay are delayed. 
(1)Confirmation of the compensated amount of each calendar day

Firstly, study on the direct loss. The cost structure and its calculation method of the direct loss included in compensated amount of each calendar day are shown in table 2.

Table 2. Index and calculation method of direct damages

\begin{tabular}{|c|c|c|c|c|}
\hline $\begin{array}{l}\text { First grade } \\
\text { indexes }\end{array}$ & $\begin{array}{l}\text { Second } \\
\text { grade } \\
\text { indexes }\end{array}$ & $\begin{array}{l}\text { Third grade } \\
\text { indexes }\end{array}$ & Calculation method & Remarks \\
\hline \multirow{7}{*}{$\begin{array}{l}\text { compensation } \\
\text { amount per } \\
\text { calendar day }\end{array}$} & \multirow{7}{*}{$\begin{array}{l}\text { direct } \\
\text { loss }\end{array}$} & loan interest & $\left(\mathrm{P}-\mathrm{P}_{1}\right) \times(\mathrm{Q} \div \mathrm{P}) \times \mathrm{R} \div 365$ & $\begin{array}{l}\mathrm{Q} \text { - the total amount of the construction project loan; } \\
\mathrm{P}_{1}-\text { the completed project price; } \mathrm{R} \text { - the loan interest } \\
\text { rate of the owner when financing. }\end{array}$ \\
\hline & & $\begin{array}{c}\text { additional } \\
\text { supervision fee }\end{array}$ & $\mathrm{P}_{2} \div \mathrm{T}$ & $\begin{array}{c}\mathrm{P}_{2} \text { is the supervision fee of this engineering, } \mathrm{T} \text { is the } \\
\text { project schedule duration }\end{array}$ \\
\hline & & $\begin{array}{l}\text { owner } \\
\text { management } \\
\text { fee }\end{array}$ & $\mathrm{P} \times \mathrm{a} \% \div \mathrm{T}$ & $\begin{array}{l}\mathrm{P} \text { is the contract price, a is the management fee rate } \\
\text { (35\% for the general power engineering, } 20 \% \text { for } \\
\text { bridge engineering, } 15 \% \text { for housing construction), } \mathrm{T} \\
\text { is the engineering project plan duration }\end{array}$ \\
\hline & & $\begin{array}{l}\text { liquidated } \\
\text { damages for } \\
\text { the Supplier }\end{array}$ & $\begin{array}{l}\text { diary liquidated } \\
\text { damages }\end{array}$ & $\begin{array}{l}\text { according to the delay stipulated by the supply } \\
\text { contract signed by the owner and the supplier, the pay } \\
\text { of the diary liquidated damages shall be accepted }\end{array}$ \\
\hline & & $\begin{array}{l}\text { liquidated } \\
\text { damages for } \\
\text { the clients }\end{array}$ & $\begin{array}{l}\text { diary liquidated } \\
\text { damages }\end{array}$ & $\begin{array}{l}\text { according to the delay stipulated by the supply } \\
\text { contract signed by the owner and the clients, the pay } \\
\text { of the diary liquidated damages shall be accepted }\end{array}$ \\
\hline & & $\begin{array}{c}\text { anti - } \\
\text { expansion } \\
\text { measure fee }\end{array}$ & $\begin{array}{l}\text { calculate according to } \\
\text { the actual conditions }\end{array}$ & $\begin{array}{c}\text { confirm according to the facts that whether the owner } \\
\text { has taken anti - expansion measures and what } \\
\text { measures are taken }\end{array}$ \\
\hline & & $\begin{array}{l}\text { force majeure } \\
\text { loss fee }\end{array}$ & $\begin{array}{l}\text { dalculate according to } \\
\text { the actual conditions }\end{array}$ & $\begin{array}{l}\text { if the loss of force majeure of the project caused by the } \\
\text { contractor, the responsibilities shall be borne by the } \\
\text { contractor }\end{array}$ \\
\hline
\end{tabular}

It can be seen from table 2 that the formula mode of the loan interest, the additional supervision fee, and the owner management fee is clear, other fees need to be determined according to the actual situation.

Secondly, study on the indirect loss. When estimating the expected profit loss, it is necessary to refer to annual average rate of profit of the similar engineering, the average profit rate of the industry in the construction area and the expected average profit rate in the feasibility study report, and modify combined with the project features based on this. The component indexes included in the indirect loss of the delay compensation and its calculation methods are summarized, as shown in table 3 .

Table 3. Index and calculation method of indirect damages

\begin{tabular}{|c|c|c|c|c|}
\hline $\begin{array}{c}\text { First grade } \\
\text { indexes }\end{array}$ & $\begin{array}{c}\text { Second } \\
\text { grade } \\
\text { indexes }\end{array}$ & $\begin{array}{c}\text { Third grade } \\
\text { indexes }\end{array}$ & $\begin{array}{c}\text { Calculation } \\
\text { method }\end{array}$ & Remarks \\
\hline & & & $\mathrm{I} \times \mathrm{R}_{1} \div 365$ & $\begin{array}{c}\text { I- the estimated annual income of the project; } \\
\text { Modify and implement according to similar } \\
\text { engineering profit rate } \mathrm{R}_{1} ;\end{array}$ \\
$\begin{array}{c}\text { Compen-sation } \\
\text { amount per } \\
\text { calendar day }\end{array}$ & indirect loss & $\begin{array}{c}\text { expected } \\
\text { profit }\end{array}$ & $\mathrm{I} \times \mathrm{R}_{2} \div 365$ & $\begin{array}{c}\text { Modify and calculate according to the } \\
\text { average rate of profit } \mathrm{R}_{2} \text { of the industry of the } \\
\text { location; }\end{array}$ \\
\cline { 4 - 5 } & & $\mathrm{I} \times \mathrm{R}_{3} \div 365$ & $\begin{array}{c}\text { Modify and calculate according to the } \\
\text { overdue annual average rate of profit } \mathrm{R}_{3} \text { in the } \\
\text { feasibility study report of the owner. }\end{array}$ \\
\hline
\end{tabular}

It can be seen from table 3 that it is possible to make a reasonable estimate of the loss of expected profits based on the above three estimated indicators.

(2)Confirmation of the delay days

In the engineering practice application, the commonly adopted calculation method ${ }^{[4]}$ as follows:

Delay days $=$ the actual completion acceptance date - the planned completion acceptance date- the days of the duration delay approved the owner. 
For the actual completion acceptance date, if the actual completion date is controversial, it shall be handled according to Article XIV of the judicial interpretation in the aspect of construction market introduced by the Supreme Court:

If the construction engineering is qualified in the completion acceptance, the qualified completion acceptance day is the completion date;

If the contractor has submitted a final acceptance report, the party issuing contract delays the acceptance, the date in which the contractor submits the acceptance report is the completion date;

If the construction project has not been completed and accepted, the party issuing contract uses without authorization, the date in which the construction engineering is transferred is the completion date.

For the planned completion acceptance date, the planned completion acceptance date shall be agreed by the contracting parties in the contract, and shall be confirmed when signing the construction contract [5]. When the calculation duration time changes caused by the owner, such as the occurrence of design changes, the planned completion date shall be re-agreed by both parties

For the days of the duration delay approved by the owner, in the event of a duration delay due to non-contractor reasons, the Contractor may file a claim of the duration to the supervising engineer, and the postponed duration days can be obtained with the agreement of the employees [6].

\subsection{The upper limit of delay compensation}

By looking for the regulations about delay compensation in the engineering construction contract of the various provinces and municipalities autonomous regions in China, it is found that five provinces and cities have clear regulations on the limitation of the delay compensation, as shown in table 4 .

Table 4. Provisions about the limitation of Delay compensations

\begin{tabular}{|c|c|c|c|}
\hline $\begin{array}{l}\text { Province } \\
\text { (city) }\end{array}$ & Contract name & Release time & $\begin{array}{l}\text { Regulations on the limitation of delay } \\
\text { compensation }\end{array}$ \\
\hline Hebei & $\begin{array}{l}\text { Construction Project } \\
\text { Contract in Hebei Province } \\
\text { (model text) }\end{array}$ & 2013 & $\begin{array}{l}\text { unless otherwise stipulated in the special terms, } \\
\text { the maximum limit of the liquidated damages for } \\
\text { delay is 5\% of the contract price after deducting } \\
\text { the tentative amount and the day work project fee }\end{array}$ \\
\hline Guangdong & $\begin{array}{l}\text { Construction Project } \\
\text { Contract in Guangdong } \\
\text { Province (model text) }\end{array}$ & 2011 & $\begin{array}{l}\text { unless otherwise stipulated in the special terms, } \\
\text { the maximum limit of the liquidated damages for } \\
\text { delay is } 5 \% \text { of the contract price }\end{array}$ \\
\hline Hubei & $\begin{array}{l}\text { Construction Project } \\
\text { Contract in Guangdong } \\
\text { Province (model text) }\end{array}$ & 2007 & $\begin{array}{l}\text { unless otherwise stipulated in the special terms, } \\
\text { the maximum limit of the liquidated damages for } \\
\text { delay is 3\% of the contract price after deducting } \\
\text { the reservation funds and the part time job project } \\
\text { fee }\end{array}$ \\
\hline Sichuan & $\begin{array}{l}\text { Construction Project } \\
\text { Contract in Sichuan } \\
\text { Province (model text) }\end{array}$ & 2011 & $\begin{array}{l}\text { unless otherwise stipulated in the special terms, } \\
\text { the maximum limit of the liquidated damages for } \\
\text { delay is } 5 \% \text { of the contract price }\end{array}$ \\
\hline Beijing & $\begin{array}{c}\text { General Contract of } \\
\text { Beijing Housing } \\
\text { Construction and } \\
\text { Municipal Infrastructure } \\
\text { Construction } \\
\end{array}$ & 2008 & $\begin{array}{l}\text { the total amount of the liquidated damages for } \\
\text { delay shall not exceed } 3 \% \text { of the contract price or } \\
\text { the maximum amount of the liquidated damages } \\
\text { for delay in the contract. }\end{array}$ \\
\hline
\end{tabular}

It can be seen from table 4 that the provinces and municipalities have no uniform provision on the maximum amount of delay compensation, so that its upper limit shall be confirmed combined with the reality.

\subsection{Reduction of delay compensation}

The 9.12.3 of Engineering Quantity List Valuation Standard of Construction Engineering (GB 50500-2013) defines the reduction of delay compensation, "before the completion of the engineering, the single (unit) engineering in the contract engineering has passes the completion acceptance, and there is no delay of completion date indicated in the acceptance certificate of the single (unit) engineering, but other parts of the contract engineering has delay, the delay compensation fee shall be 
in accordance with the proportion range of the single (unit) engineering cost of the issued engineering acceptance certificate occupying the contract price. In the engineering practice, the reduction of delay compensation means that when a large-scale project needs to have sub-node construction, if the overall project fails to pass the acceptance in the agreed acceptance date, so that the duration delay is caused, and one section in the earlier stage has been completed and the acceptance certificate is issued, the delay compensation amount paid shall be reduced according to the proportion of the current completed section in the total contract price ${ }^{[7]}$.

\section{Summary}

Based on the research on the calculation method and limit of the delay compensation, it is not difficult to find that the reasonable agreement on the delay compensation between the contracting parties in the special terms of the contract is important to make up the loss suffered by the owner due to the delay, and also to the performance of the contract and the realization of the contract project. When the delay event occurs, the two sides shall reasonably determine the delay compensation fee, in accordance with the nature of the delay compensation, aiming at the actual loss suffered by the owner and according to the proper procedures.

\section{References}

[1] Lv Shengpu, Yin Yilin. The Study of Time and Cost Claims Based on FIDIC Contract Conditions[D].Tianjin: Tianjin University of Technology,2006.

[2] Yang Deqin, The Claim is Bidirectional[J]. Building Economy,2004(06):40-42.

[3] Zhang Mingfeng,Zhang Chunming. Overdue Damage Compensation in FIDIC[J]. International Economic Cooperation. 2002(07):56-58.

[4] Li Qingxun. The Composition and Calculation of the Claim Caused by Delay in the Construction of International Projects[J].Project Management Technology, 2009 (11):61-63.

[5] Yang Deqin. Study on the Principle of Delay Claims with Multi-event Interference[J]. China Civil Engineering Journal, 2003(03):40-45..

[6] Qiao Baihe. Project Claim Management and Time Limit for a Project Delay Claim [D] Xian: Chang 'an University,2006.

[7] Zhang Zhihui, He Qianru. Impact of Packaging on the Cost of Highway Construction Projects [J]. J Tsinghua Univ(Sci\& Tech),2010 (06):830-833. 